\title{
Levels of selected essential and non-essential metals in seeds of korarima (Aframomum corrorima) cultivated in Ethiopia
}

\author{
Níveis de metais essenciais e não essenciais selecionados em sementes de korarima \\ (Aframomum corrorima) cultivadas na Etiópia
}

\section{Autores | Authors \\ Birhanu MEKASSA \\ Addis Ababa University ( $A A U$ ) Faculty of Science Department of Chemistry Addis Ababa - Ethiopia e-mail: birhanume@gmail.com \\ *Bhagwan Singh CHANDRAVANSHI \\ Addis Ababa University (AAU) Faculty of Science Department of Chemistry P.O. Box 1176, King George VI St Addis Ababa - Ethiopia e-mail: bscv2006@yahoo.com}

*Autor Correspondente / Corresponding Author

Received: Sept.10, 2014

Approved: June 11, 2015

\section{Summary}

The levels of essential ( $\mathrm{Ca}, \mathrm{Mg}, \mathrm{Fe}, \mathrm{Zn}, \mathrm{Cu}, \mathrm{Co}, \mathrm{Cr}, \mathrm{Mn}$ and $\mathrm{Ni}$ ) and non-essential $(\mathrm{Cd}$ and $\mathrm{Pb})$ metals were determined by flame atomic absorption spectrometry in samples of korarima (Aframomum corrorima) seeds and the corresponding soils collected from southern and southwestern Ethiopia. A wet digestion procedure involving the use of $3 \mathrm{~mL}$ of $\mathrm{HNO}_{3}(69-72 \%)$ and $1 \mathrm{~mL}$ of $\mathrm{HClO}_{4}(70 \%)$ were used to solubilize the metals from the korarima seed samples, and a modified aqua regia $\left(\mathrm{HCl}: \mathrm{HNO}_{3}\right)$ reagent with added hydrogen peroxide ( $6 \mathrm{~mL}$ of aqua regia and $1.5 \mathrm{~mL}$ of $\mathrm{H}_{2} \mathrm{O}_{2}$ ) was used for the soil samples. The levels of the nutrients in the korarima seed samples were in the following ranges: $\mathrm{Ca}$ (1794-2181); Mg (1626-2067); Mn (141-180); Fe (37-46); Zn (12-18); Ni (6.6-8.5); $\mathrm{Cu}$ (5.8-8.3); Cr (3.8-5.8) and Co (2.0-2.3) in $\mu_{\mathrm{g} \mathrm{g}}{ }^{-1}$, respectively. The concentration of non-essential cadmium was in the range from $0.9-1 \mu^{-1} \mathrm{~g} \mathrm{~g}^{-1}$ while that of lead was below the detection limit of the method. There was good correlation between the levels of some metals ( $\mathrm{Ni}, \mathrm{Fe}, \mathrm{Cd}, \mathrm{Ca}, \mathrm{Cu}, \mathrm{Mg}$ ) in the korarima seeds and soil samples but poor correlation between other metals ( $\mathrm{Cr}, \mathrm{Zn}, \mathrm{Mn}, \mathrm{Co})$.

Key words: Ethiopia; Korarima (Aframomum corrorima); Seed; Wet-digestion; Metals; Flame atomic absorption spectrometry (FAAS).

\section{Resumo}

Os níveis dos metais essenciais ( $\mathrm{Ca}, \mathrm{Mg}, \mathrm{Fe}, \mathrm{Zn}, \mathrm{Cu}, \mathrm{Co}, \mathrm{Cr}, \mathrm{Mn}$ e Ni) e não essenciais $(\mathrm{Cd}$ e $\mathrm{Pb})$ foram determinados por espectrometria de absorção atômica de chama em amostras de sementes de korarima (Aframomum corrorima) e também nos solos correspondentes colhidos no sul e sudoeste da Etiópia. Um procedimento de digestão úmida envolvendo o uso de $3 \mathrm{~mL} \mathrm{HNO}$ (69-72\%) e $1 \mathrm{~mL} \mathrm{HClO}_{4}$ (70\%) foi usado para solubilizar os metais das amostras de sementes de korarima, e um reagente de água-régia $\left(\mathrm{HCl} \mathrm{HNO}_{3}\right)$ modificada pela adição de peróxido de hidrogênio ( $6 \mathrm{~mL}$ de água-régia e 1,5 $\mathrm{mL} \mathrm{H}_{2} \mathrm{O}_{2}$ ) foi usada para as amostras de solo. Os níveis dos nutrientes nas amostras de sementes de korarima estavam nas seguintes faixas: $\mathrm{Ca}$ (1794-2181); Mg (1626-2067); Mn (141-180); $\mathrm{Fe}(37-46) ; \mathrm{Zn}(12-18) ; \mathrm{Ni}(6,6-8,5) ; \mathrm{Cu}(5,8-8,3) ; \mathrm{Cr}(3,8-5,8)$; e Co $(2,0-2,3)$ em $\mu \mathrm{g} \mathrm{g^{-1 }}$, respectivamente. A concentração de cádmio não essencial estava na faixa de $0.9-1 \mu^{~ g ~ g}{ }^{-1}$ enquanto o valor para chumbo foi abaixo dos limites de detecção do método. Houve boa correlação entre os níveis dos metais $\mathrm{Ni}, \mathrm{Fe}, \mathrm{Cd}$, Cu e Mg, nas sementes de korarima e nas amostras de solo, mas pouca correlação entre o restante dos metais ( $\mathrm{Cr}, \mathrm{Zn}, \mathrm{Mn}, \mathrm{Co})$.

Palavras-chave: Etiópia; Korarima (Aframomum corrorima); Semente; Digestão úmida; Metais; Espectrometria de absorção atômica de chama. 


\section{Introduction}

Spices and herbs are used throughout the world to season food products and create the unique characteristic flavours of the different cuisines. The delightful flavour and pungency of spices makes them indispensable in the preparation of palatable dishes. In addition, they are reputed to possess several medicinal and pharmacological properties and hence find their place in the preparation of a number of medicines (RISCH, 1997; LEISTRITZ, 1997). A spice is a dried seed, fruit, root, bark or vegetable substance, primarily used as ingredients for flavouring, colouring or preserving food. They impart aroma, colour and taste to food preparations and sometimes mask undesirable odours. Their aroma results from complex mixtures of volatile compounds, e.g. monoterpenes and sesquiterpenes and their oxygenated derivatives, which usually occur in low concentrations (UMAR; SALIHU, 2014; DIAZMAROTO et al., 2002; ETONIHU et al., 2013).

Ethiopia is a land of diverse climate and soil types that allows for the prolific growth of several indigenous and exotic spices, herbs, medicinal and other essential oil bearing plants. Despite the availability of the diverse agro-ecologies of the country to produce these plant species, only limited research has been carried out with them, for a variety of reasons.

Korarima (Aframomum corrorima) is an important spice and medicinal plant in large areas of Ethiopia, but is little known outside the country. This indigenous Ethiopian spice, known as korarima, Ethiopian cardamom or false cardamom, is obtained from the plant seeds (usually dried), and is extensively used in Ethiopian and Eritrean cuisine (EYOB et al., 2009). The seeds (usually dried, sometimes fresh) are used to flavour all kinds of sauces locally called 'wot', for which they are ground and usually mixed with other spices. Korarima is sold in all markets in Ethiopia, and is used daily by most families in rural areas. It is used to add flavour to local food, bread and butter, is an ingredient of berbere, mitmita, awaze and other spice mixtures, and is also used to flavour coffee. In addition, korarima seeds are widely used medicinally as a tonic, laxative, carminative and purgative drug, and they are added to food for preservative purposes. Although korarima is consumed as a spice, it may also be used as a source of antioxidants, and the arilloid flesh around the seed is edible. Strings of fruits are sometimes used as an ornament or as rosaries (by the Arabs), and in the past the fruits have been used as money in Ethiopia. In addition, korarima is an important plant for soil conservation since the rhizomes and leaves spread over the ground covering and protecting the soil from erosion in hilly areas. It is primarily the red fruits that are used, but other parts of the plant can also be used. The taste of korarima is similar to that of Indian cardamom, and it has been used as a substitute for this spice (EYOB, 2009; HYMETE et al., 2006; TEFERA; WANNAKRAIROJ, 2006).

The widespread contamination with heavy metals occurring in the last decade has raised public and scientific concern due to its serious health effects on humans. This has encouraged researchers to study the pollution levels of heavy metals in the air, water and foods, aiming to avoid their harmful effects and to determine their permissibility for human consumption (AL-EED et al., 2002). The accumulation of heavy metals can have middle and long term health risks, and the strict periodic surveillance of these contaminants is therefore advisable (ETONIHU et al., 2013). Although spices and herbs represent extremely small amounts of the total food intake, considerable levels of heavy metals may occur in these plants when they are grown in contaminated soils. Thus the monitoring of the toxicity levels of heavy metals in herbs and spices has recently been reported in different parts of the world (KREJPCIO et al., 2007).

Although much research has been carried out on the medicinal value and chemical composition of essential oils (EYOB et al., 2007, 2008, 2009; HYMETE et al., 2006; TEFERA; WANNAKRAIROJ, 2006) no report was found on the assessment of the metal contents of korarima (Aframomum corrorima) samples, although exposure of the plants to the metals is inevitable. Thus this study aimed to fill this gap, at least partially, and initiate other studies on closely related spices widely used throughout the country. In the present study, the levels of selected essential ( $\mathrm{Ca}, \mathrm{Mg}, \mathrm{Fe}, \mathrm{Zn}, \mathrm{Cu}, \mathrm{Co}, \mathrm{Cr}, \mathrm{Mn}$ and $\mathrm{Ni}$ ), and non-essential ( $\mathrm{Cd}$ and $\mathrm{Pb}$ ) metals in korarima seed samples collected from selected highlands of southern and southwestern Ethiopia (Kaffa, Gamo Gofa and Illubabor) were determined using flame atomic absorption spectrometry.

\section{Material and methods}

\subsection{Apparatuses and instrument}

Polyethylene plastic bags, hot plates, a blender (Moulinex, France), porcelain mortar, pestles and crucibles (Haldenwanger, Germany), and an analytical balance (Switzerland) with a precision of $\pm 0.0001 \mathrm{~g}$ were used for the transporting, drying, pounding and weighing of the samples. Round bottomed flasks (100 mL) fitted with reflux condensers set on Kjeldahl heating apparatus (Gallenhamp, England) were employed to digest the samples. A flame atomic absorption spectrophotometer (Buck Scientific, Model 210VGP AAS, USA) equipped with a deuterium background corrector and hollow cathode lamps with an air-acetylene flame, were used for the determinations of eleven (Ca, Mg, Fe, Zn, Cu, Co, Cr, Mn, $\mathrm{Ni}, \mathrm{Cd}$ and $\mathrm{Pb}$ ) metals. 


\subsection{Chemicals and reagents}

All the reagents and chemicals used in the study were of analytical grade. For digestion purposes, $69-72 \% \mathrm{HNO}_{3}$ and $70 \% \mathrm{HClO}_{4}$ (both from Research-lab Fine Chem Industries, Mumbai, India), extra pure $30 \% \mathrm{H}_{2} \mathrm{O}_{2}$, (Scharlau, European Union), and 37\% $\mathrm{HCl}$ (Rediel-de-Haen, Germany), were employed. 99.9\% Lanthanum nitrate hydrate (Aldrich, USA) was also used to avoid refractory interference on the $\mathrm{Ca}$ and $\mathrm{Mg}$ from their phosphates. Standard stock solutions of each metal were used to prepare intermediate standard solutions. Distilled and deionized water were used throughout the experiment for sample preparation, dilution and rinsing of the apparatus.

\subsection{Korarima and soil sampling and the pre-treatment}

Recently harvested matured red korarima capsule samples were collected from three study sites: Bonga, located in the Kaffa zone of the Southern Nations Nationalities and Peoples Regional (SNNPR) state, Kemba in the Gamo Gofa zone of the Southern Nations Nationalities and Peoples Regional state, and Metu, Illubabor zone, in Oromia. The sampling areas are shown in Figure 1. The choices of the study sites were made on the basis of the major korarima producing regions in Ethiopia. For each main site, three sub-sites, about $20 \mathrm{~km}$ apart from each other, were designated for the purpose of random sampling. At each particular sub-site, four neighbourhood farmers were selected at random and the matured red korarima capsules were collected directly from the plant material on the farm land to get a total sample of about $500 \mathrm{~g}$. Finally all the samples collected from each sub-site were mixed in a single polyethylene plastic bag to obtain one $1.5 \mathrm{~kg}$ representative bulk

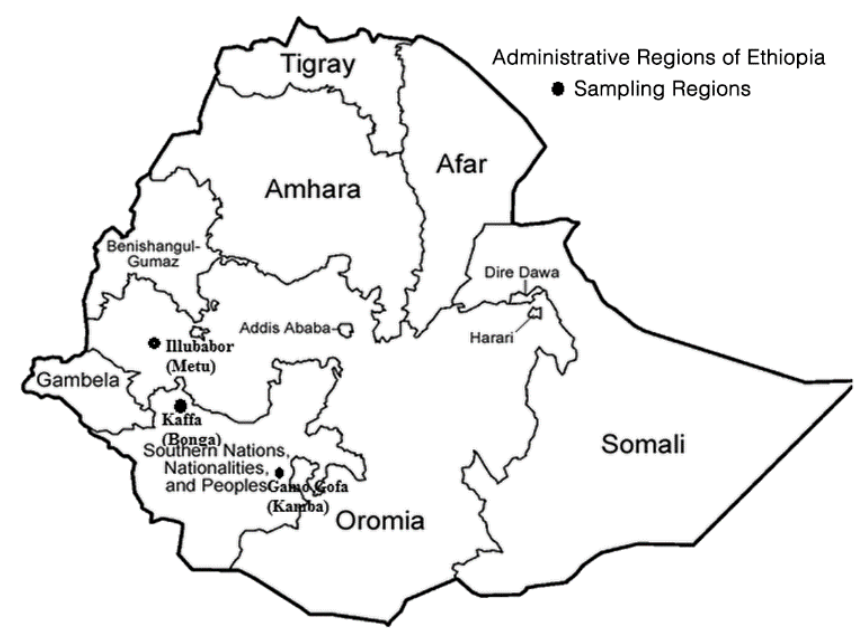

Figure 1. Map showing the administrative regions of Ethiopia from where the samples were collected. sample of matured red korarima capsules. The samples collected were then packaged into polyethylene plastic bags, labelled and transported to the laboratory for further treatment.

For each of the korarima capsule samples the outer cover was carefully removed and the clean brown coloured seeds were collected. The seed samples were then placed in clean, acid washed porcelain crucibles labelled according to the sampling site, and dried over a hot plate and sun-dried until they become brittle. The dried korarima seed samples were then pounded into fine particles, homogenized with a blending device (Moulinex, France), and stored in polyethylene bags for digestion.

Similarly, the soil samples were collected from the same sites as the korarima capsules by digging and removing the soil samples from between 10 and $15 \mathrm{~cm}$ in depth. About $500 \mathrm{~g}$ of soil were taken from each particular sub-site where the korarima plants were growing, and then mixed together in a single clean plastic bag to obtain one bulk sample. The samples were placed in clean polyethylene plastic bags and taken to the lab for further pre-treatment. After sun drying, the soil samples were pounded into a fine powder in a porcelain mortar and pestle and then sieved through a $500 \mu \mathrm{m}$ mesh sieve. The powdered sample was stored in a pre-cleaned screw capped polyethylene container until digestion.

Since the korarima spice is also called false cardamom or Ethiopian cardamom and is used as a substitute for Indian cardamom on the world market, it was compared with the Indian cardamom obtained from three Ethiopian supermarkets (Friendship, Abadir and Showa) in Addis Ababa, the capital of Ethiopia. About $250 \mathrm{~g}$ of cardamom sample was bought from each supermarket and then mixed to get one bulk sample.

\subsection{Wet digestion of the korarima seed samples}

$0.5 \mathrm{~g}$ of the powdered and homogenized korarima seed samples were placed in a $100 \mathrm{~mL}$ round bottomed flask and $3 \mathrm{~mL}$ concentrated $\mathrm{HNO}_{3}(69-72 \%)$ and $1 \mathrm{~mL}$ of $\mathrm{HClO}_{4}(70 \%)$ added. The mixture was then digested using a Kjeldahl digestion apparatus by setting the temperature to dial $4\left(120^{\circ} \mathrm{C}\right)$ for $30 \mathrm{~min}$ followed by dial $7\left(210^{\circ} \mathrm{C}\right)$ for $120 \mathrm{~min}$ until a clear solution was obtained, following the optimized digestion procedure. After a total of $150 \mathrm{~min}$, the digested solutions were allowed to cool for 10 min without dismantling the condenser and then for a further 10 min after removing the condenser from the flask. Two $5 \mathrm{~mL}$ portions of distilled-deionized water were added to the cooled solution to dissolve the precipitate formed on cooling. The cooled digested samples were filtered into a $50 \mathrm{~mL}$ standard flask through a Whatman filter paper $(110 \mathrm{~mm})$ to remove any suspended or turbid matter. The filtrate was subsequently rinsed with $5 \mathrm{~mL}$ distilled-deionized water, until the volume reached 
around $45 \mathrm{~mL} .1 \mathrm{~mL}$ of $1 \%$ lanthanum nitrate hydrate (matrix modifier) was added to each digested sample to liberate calcium and magnesium, in case large amounts of phosphate existed in the sample. The volume was then completed to the mark $(50 \mathrm{~mL})$ with distilled-deionized water. For each korarima seed sample, triplicate digestions were carried out and blank solutions were also digested in triplicate. The optimized digestion procedure used for the korarima seed samples was also applied to the cardamom samples.

\subsection{Wet digestion of the soil samples}

For this process, $0.5 \mathrm{~g}$ of each well-powdered soil sample was placed in a round bottomed flask and $6 \mathrm{~mL}$ of aqua-regia and $1.5 \mathrm{~mL}$ of hydrogen peroxide $\left(\mathrm{H}_{2} \mathrm{O}_{2}\right)$ added. The samples were digested on a micro Kjeldahl digestion apparatus, setting the temperature first at 120 ${ }^{\circ} \mathrm{C}$ for $30 \mathrm{~min}$, then increasing to $240{ }^{\circ} \mathrm{C}$ for the next 30 min, and finally heating at $270{ }^{\circ} \mathrm{C}$ for the remaining 120 min. After 3:00 hour, the digest was allowed to cool for a total of $20 \mathrm{~min}$ (10 min without removing the condenser and 10 min after removing the condenser). Distilleddeionized water was added to dissolve the precipitate formed on cooling. The cooled digested samples were filtered into a $50 \mathrm{~mL}$ standard flask through a Whatman filter paper using distilled-deionized water. To this solution, $1 \mathrm{~mL}$ of $1 \%$ lanthanum nitrate hydrate solution was added and the solution was diluted to the mark $(50 \mathrm{~mL})$ with distilled-deionized water.

\subsection{Instrument calibration and method detection limit}

In order to calibrate the instrument, standard metal calibration solutions were prepared for each of the metals from an intermediate standard solution ( $\left.10 \mathrm{mg} \mathrm{L}^{-1}\right)$, made by diluting $1000 \mathrm{mg} \mathrm{L}^{-1}$ of stock AAS metal standard solution. After the digestion of two blank solutions in triplicate (one using a mixture of $3 \mathrm{~mL} \mathrm{HNO}$ and $1 \mathrm{~mL} \mathrm{HClO}$ for the wet digestion of the korarima seed samples and a mixture of aqua-regia and hydrogen peroxide for the digestion of the soil samples), triplicate readings were obtained for each sample. The limit of detection of each element was then calculated as three times the standard deviation of the blank $\left(3 \sigma_{\text {blank, }} n=9\right)$. The values obtained for the limit of detection were low enough $\left(\leq 2 \mu \mathrm{g} \mathrm{g}^{-1}\right)$ to detect the presence of all the metals except lead, in both the seed and soil samples. The correlation coefficient $(r)$ obtained for the calibration curve was also greater than 0.997 for all the metals studied.

\subsection{Method validation}

In order to determine the reliability and efficiency of the optimized digestion procedure developed, spiked experiments, in which known volumes and concentrations of standard solutions were added, were employed. From the stock solutions of $\left(1000 \mathrm{mg} \mathrm{L}^{-1}\right), 196.0 \mu \mathrm{L}$ of $\mathrm{Ca}$, $162.5 \mu \mathrm{L}$ of $\mathrm{Mg}, 10.5 \mu \mathrm{L}$ of $\mathrm{Fe}, 36.0 \mu \mathrm{L}$ of $\mathrm{Mn}$ and $4.25 \mu \mathrm{L}$ of the $\mathrm{Zn}$ solutions were added to $0.5 \mathrm{~g}$ of the korarima seed sample. For the rest of the metals an intermediate standard solution (10 $\mathrm{mg} \mathrm{L}^{-1}$ ) was prepared and 200.0 $\mu \mathrm{L}$ of $\mathrm{Cu}, 75.0 \mu \mathrm{L}$ of $\mathrm{Co}, 150.0 \mu \mathrm{L}$ of $\mathrm{Cr}, 200.0 \mu \mathrm{L}$ of $\mathrm{Ni}$ and $25.0 \mu \mathrm{L}$ of the $\mathrm{Cd}$ solutions were added to the 0.5 $\mathrm{g}$ of korarima seed sample. Similarly, $100.0 \mu \mathrm{L}$ of $\mathrm{Ca}$, 181.5 $\mu \mathrm{L}$ of $\mathrm{Mg}, 130.0 \mu \mathrm{L}$ of $\mathrm{Fe}$, and $97.0 \mu \mathrm{L}$ of $\mathrm{Mn}$ were taken from $1000 \mathrm{mg} \mathrm{L}^{-1}$ stock solutions. Intermediate standard solutions of $10 \mathrm{mg} \mathrm{L}^{-1}$ were prepared from the stock solutions of (1000 $\mathrm{mg} \mathrm{L}^{-1}$ ) and $400.0 \mu \mathrm{L}$ of $\mathrm{Zn}, 275.0$ $\mu \mathrm{L}$ of $\mathrm{Cu}, 80.0 \mu \mathrm{L}$ of $\mathrm{Co}, 275.0 \mu \mathrm{L}$ of $\mathrm{Cr}, 500.0 \mu \mathrm{L}$ of $\mathrm{Ni}$ and $40.0 \mu \mathrm{L}$ of $\mathrm{Cd}$ were added to the soil sample. $\mathrm{Ca}, \mathrm{Mg}$, Fe, $\mathrm{Mn}$ and $\mathrm{Ni}$ were spiked into one of the digestion samples in triplicate while $\mathrm{Zn}, \mathrm{Cu}, \mathrm{Co}, \mathrm{Cr}$ and $\mathrm{Cd}$ were spiked into the second set of samples, in triplicate. The samples were then digested using the procedures optimized for both the korarima seed and soil samples. After diluting the digested samples to $25 \mathrm{~mL}$ with distilled deionized water, they were analysed by the same procedure followed for the analysis of the korarima seed and soil samples. As in the case of the original samples, triplicate spiked samples were prepared and triplicate readings recorded. The precision and accuracy of the procedures were determined from these determinations. The percentage recovery varied from 90 to $109 \%$ for the korarima seed and 90.0 to $104 \%$ for the soil samples, both are within the acceptable range.

\subsection{Analytical precision}

In this study the precision of the results was evaluated from the pooled standard deviation and relative standard deviation of the triplicate samples, with triplicate measurements of each sample $(n=9)$. The values obtained for the relative standard deviations (\% RSD) were less than $10 \%$ for all the samples, showing the good precision of this method.

\subsection{Statistical analysis}

The comparison of variance and the equality of the means in the analyses and sampling as well as the correlation between the metals in the korarima seed and soil samples, were determined separately using the One Way ANOVA using origin 6.0 and Microsoft Excel Software.

\section{Results and discussion}

\subsection{Levels of metals in the korarima seed and soil samples}

The korarima seed and soil samples were analysed for essential ( $\mathrm{Ca}, \mathrm{Mg}, \mathrm{Fe}, \mathrm{Cu}, \mathrm{Mn}, \mathrm{Zn}, \mathrm{Cr}$ and $\mathrm{Co}$ ) and non-essential ( $\mathrm{Cd}$ and $\mathrm{Pb}$ ) metals using FAAS. Table 1 
shows the values obtained together with the standard deviations $($ mean \pm SD) of the triplicate analysis for the korarima seed and soil samples. The results indicated that, with the exception of $\mathrm{Pb}$, which was below the method detection limit, all the other ten metals ( $\mathrm{Ca}, \mathrm{Mg}, \mathrm{Fe}, \mathrm{Zn}, \mathrm{Cu}$, $\mathrm{Co}, \mathrm{Cr}, \mathrm{Mn} \mathrm{Ni}$, and Cd) were detected (Table 1). However, the levels of the metals differed significantly from one to the other and slightly between the korarima samples cultivated in different zones. There was also a difference in metal concentrations between the korarima seed and Indian cardamom analysed for comparison. The trends in the variation of the metals in the korarima seed samples were $\mathrm{Ca}>\mathrm{Mg}>\mathrm{Mn}>\mathrm{Fe}>\mathrm{Zn}>\mathrm{Ni}>\mathrm{Cu}>\mathrm{Cr}>\mathrm{Co}>\mathrm{Cd}$, while for the soil samples they were as follows $\mathrm{Fe}>\mathrm{Mg}>\mathrm{Ca}>$ $\mathrm{Mn}>\mathrm{Ni}>\mathrm{Zn}>\mathrm{Cu}>\mathrm{Cr}>\mathrm{Co}>\mathrm{Cd}$. The results indicated that calcium was highly absorbed by the plant while cadmium was the least determined in all the samples.

\subsection{Distribution pattern of the metals in the korarima and soil samples}

Although the metal levels in both the korarima seed and cardamom samples (analysed for the sake of comparison) were comparable, higher metal concentrations were determined in the cardamom samples in almost all cases, except for cadmium, which was slightly higher in the korarima seed samples. Amongst the korarima seed samples, higher metal concentrations were determined in samples collected from Metu, and the lowest concentrations for samples collected from Gamo Gofa, except for cadmium. Lead was not detected in samples collected from any of the three sites.

The metal levels in the soil samples followed almost the same trend as those found in the korarima samples brought from each zone. Larger amounts of metals were determined in samples collected from Metu and smaller amounts in the samples from Gamo Gofa, except for $\mathrm{Mn}$ and $\mathrm{Cd}$, for which the highest concentrations were determined in the Bonga and Gamo Gofa samples, respectively. The highest concentration found was for Fe $\left(29301 \pm 677 \mu \mathrm{g} \mathrm{g}^{-1}\right.$ dry weight) and the lowest for $\mathrm{Cd}$ $\left(1.8 \pm 0.04 \mu \mathrm{g} \mathrm{g}^{-1}\right)$ both brought from Metu (Table 1).

\subsection{Specific distribution patterns of the metals}

Calcium was the metal found in highest concentrations in the korarima seed samples. The highest levels of calcium were observed in the korarima seed and soil samples collected from Metu and the lowest in the samples from Gamo Gofa samples. High concentrations of $\mathrm{Ca}$ are important because of its role in bones, teeth, muscle systems and heart functions; and the present study shows satisfactory levels of $\mathrm{Ca}$ accumulation.

Magnesium was the second most accumulated metal in both the korarima seed and soil samples analysed in this study. The results revealed relatively higher concentrations of magnesium in the korarima seed and soil samples collected from Metu than from the other sampling sites.

The higher concentrations of $\mathrm{Ca}$ and $\mathrm{Mg}$ in the korarima seeds evaluated in this study is in agreement with previous findings that these metals represent the most abundant metal constituents of many plants, which might be attributed to the high availability of the soluble forms of these metals that can be absorbed.

Of all the metals, the iron content was several times higher than that of the other metals determined in the soil samples studied, varying from 23570 to $29301 \mathrm{\mu g} \mathrm{g}^{-1}$ in the soil. The level of iron in the korarima seeds ranged from 37 to $46 \mathrm{\mu g} \mathrm{g}^{-1}$, indicating a low availability of soluble iron in the soil. The permissible limit set by FAO (1984) for edible plants is $20 \mathrm{\mu g} \mathrm{g}^{-1}$, but the results found in the

Table 1. Average concentrations (mean $\pm S D)$ in $\mu g g^{-1}$ dry weight, $(n=9)$ for the metals in the korarima seed, cardamom and soil samples collected in the different zones.

\begin{tabular}{|c|c|c|c|c|c|c|c|}
\hline \multirow{2}{*}{ Metals } & \multicolumn{3}{|c|}{ Korarima } & \multirow{2}{*}{$\frac{\text { Cardamom }}{\text { Addis Ababa }}$} & \multicolumn{3}{|c|}{ Soil } \\
\hline & Bonga & Gamo Gofa & Metu & & Bonga & Gamo Gofa & Metu \\
\hline $\mathrm{Ca}$ & $1959 \pm 23$ & $1794 \pm 43$ & $2181 \pm 59$ & $2719 \pm 35$ & $1002 \pm 24$ & $665 \pm 69$ & $1048 \pm 77$ \\
\hline $\mathrm{Mg}$ & $1626 \pm 34$ & $1699 \pm 29$ & $2067 \pm 61$ & $2390 \pm 41$ & $1818 \pm 157$ & $1170 \pm 53$ & $2469 \pm 82$ \\
\hline $\mathrm{Fe}$ & $43 \pm 4$ & $37 \pm 1$ & $46 \pm 4$ & $65 \pm 2$ & $26357 \pm 526$ & $23570 \pm 861$ & $29301 \pm 677$ \\
\hline $\mathrm{Zn}$ & $17 \pm 1$ & $12 \pm 1$ & $18 \pm 1$ & $20 \pm 1$ & $16.3 \pm 0.2$ & $16.9 \pm 1.3$ & $21.4 \pm 1.2$ \\
\hline $\mathrm{Cu}$ & $8.3 \pm 0.1$ & $5.8 \pm 0.4$ & $7.1 \pm 0.2$ & $9.5 \pm 1$ & $12.6 \pm 0.4$ & $10.2 \pm 0.9$ & $12.9 \pm 0.6$ \\
\hline Co & $2.2 \pm 0.2$ & $2.0 \pm 0.03$ & $2.3 \pm 0.2$ & $2.6 \pm 0.2$ & $2.7 \pm 0.1$ & $2.8 \pm 0.2$ & $2.9 \pm 0.1$ \\
\hline $\mathrm{Cr}$ & $5.8 \pm 0.4$ & $3.8 \pm 0.3$ & $5.6 \pm 0.4$ & $8.3 \pm 0.7$ & $11.0 \pm 0.8$ & $10.9 \pm 0.5$ & $11.4 \pm 0.4$ \\
\hline $\mathrm{Mn}$ & $144 \pm 5$ & $141 \pm 2$ & $180 \pm 4$ & $355 \pm 9.8$ & $971 \pm 37$ & $730 \pm 8$ & $947 \pm 38$ \\
\hline $\mathrm{Ni}$ & $8.3 \pm 0.7$ & $6.6 \pm 0.5$ & $8.5 \pm 0.2$ & $11.7 \pm 0.5$ & $19.8 \pm 0.3$ & $16.3 \pm 0.5$ & $20.4 \pm 0.6$ \\
\hline $\mathrm{Pb}$ & ND & ND & ND & ND & ND & ND & ND \\
\hline $\mathrm{Cd}$ & $0.9 \pm 0.05$ & $1.0 \pm 0.1$ & $0.99 \pm 0.04$ & $0.87 \pm 0.07$ & $1.3 \pm 0.02$ & $2.0 \pm 0.09$ & $1.8 \pm 0.04$ \\
\hline
\end{tabular}

$\mathrm{ND}=$ not detected (concentrations were below the method detection limit, $2.0 \mu \mathrm{g} \mathrm{g}^{-1}$ ); Bonga, Gamo Gofa and Metu are regions from where the korarima and soil samples were collected; the cardamom samples were bought from a supermarket in Addis Ababa. 
present study are higher than this limit, at all the sites studied. Fe is necessary for the formation of haemoglobin and also plays an important role in oxygen and electron transfer in the human body (JABEEN et al., 2010). Iron deficiency is the most prevalent nutritional deficiency in humans and therefore, frequent consumption of this spice could be used as a source of this essential nutrient.

Zinc is an important essential metal in protein synthesis, enzymes, energy production, and in maintaining the membranes (RANDJELOVIC et al., 2014). While the highest level of zinc was observed in the Metu samples, the lowest level of zinc was found in the Gamo Gofa and Bonga samples for the korarima seeds and soil samples, respectively. The permissible limit set by FAO (1984) for edible plants is $27.4 \mu_{\mathrm{g} \mathrm{g}}{ }^{-1}$, which is higher than that found in the present study.

Copper is one of the essential micronutrients and its adequate supply for growing plants should be ensured through artificial or organic fertilizers (DIVRIKLI et al., 2006). In the present work, the copper concentration was from 5.8 to $8.3 \mu_{\mathrm{g} \mathrm{g}}{ }^{-1}$ in the korarima seeds and from 10.2 to $12.9 \mu \mathrm{g} \mathrm{g}^{-1}$ in the soil samples. The highest copper levels were found in the Bonga seed samples and Metu soil samples. The Gamo Gofa samples contained the lowest copper concentrations in both the seed and soil samples analysed. The principal source of copper might be from the soil or soil contaminants. The permissible limit set by FAO (1984) for edible plants is $3.00 \mu \mathrm{g} \mathrm{g}^{-1}$ or less, but values of 4 to $15 \mu \mathrm{g} \mathrm{g}^{-1}$ have been cited in agricultural products (JABEEN et al., 2010), in agreement with the present study.

The cobalt concentrations ranged from 2.0 to $2.3 \mu \mathrm{g} \mathrm{g}^{-1}$ in the korarima seed samples, and from 2.7 to $2.9 \mu_{\mathrm{g} \mathrm{g} \mathrm{g}^{-1}}$ in the corresponding soil samples in the regions studied. The lowest cobalt concentrations were found in the Bonga seed samples and Gamo Gofa soil samples. Cobalt was the second smallest trace metal determined next to cadmium, in both the korarima seed and soil samples. The only known nutritional, but very vital, function of cobalt, is as an integral part of vitamin $B_{12}$. However, there is no evidence that the intake of cobalt is ever limiting in the human diet, and no RDA is necessary (NRC, 1989a,b).

The chromium contents of the korarima seed samples evaluated in this study were in the following order with respect to the sites: Bonga > Gamo Gofa > Metu and the results for the soil samples were in the same order. The trivalent chromium, $\mathrm{Cr}(\mathrm{III})$, is an essential trace element for adult human beings, with a daily requirement of 50-200 $\mu \mathrm{g}$, being toxic only at high levels, although chronic exposure to $\mathrm{Cr}$ may result in liver, kidney and lung damage (JABEEN et al., 2010). The tolerable limit set by FAO (1984) for $\mathrm{Cr}$ in edible plants is $0.02 \mu \mathrm{g} \mathrm{g}^{-1}$, and the present study showed that the korarima plant accumulates Cr above this limit.

Manganese was the third and fourth most accumulated metal in the korarima seed and soil samples, respectively, with concentrations between 144 and $180 \mu^{-1} \mathrm{~g}^{-1}$ for the korarima seeds and between 730 and $971 \mu^{-1} g^{-1}$ for the soil samples. Manganese activates numerous essential enzymes and food contains trace amounts. Higher manganese concentrations were expected because it accumulates mostly in plant leaves and also because the absorption of soluble $\mathrm{Mn}$ increases with decreasing soil pH (DIVRIKLI et al., 2006; AJASA et al., 2004). A daily dietary intake of 2.5 to $5 \mathrm{mg}$ of manganese by human beings contributes to the well-being of the cells. A deficiency of manganese causes diseases and an excess causes poisoning of the central nervous system. The absorption, ingestion, inhalation or skin contact with manganese may cause manganic pneumonia (HASHMI et al., 2007). The permissible limit set by FAO (1984) for edible plants is $2 \mu \mathrm{g} \mathrm{g}^{-1}$.

Nickel also plays some roles in body functions including enzyme functions. In very small amounts, it may be beneficial to activate some enzyme systems, but its toxicity at higher levels is more evident. However, nickel toxicity is not very common in humans because nickel absorption is very low (DIVRIKLI et al., 2006). In the present study the nickel content was in the range from 6.6 to $8.5 \mu^{-1} g^{-1}$ for the korarima seed samples and from 16.3 to $20.4 \mu^{-1} \mathrm{~g}^{-1}$ for the soil samples, and there was no significance difference between the levels of nickel determined at the different sites. The permissible limit set by FAO (1984) for nickel in edible plants is $1.63 \mu_{\mathrm{g} \mathrm{g}}{ }^{-1}$, higher than that found in the present study.

Cadmium is a nonessential element in foods and natural waters and accumulates principally in the kidneys and liver. In foods cadmium is mostly derived from a variety of environmental contamination sources (DIVRIKLI et al., 2006). Currently there is considerable interest in $\mathrm{Cd}$ in plant nutrition and the cadmium levels in plant materials are in the range from 0.1 to $1.0 \mu \mathrm{g} \mathrm{g}^{-1}$. Toxic effects have been observed in man from the regular consumption of plants in excess of $3 \mu \mathrm{g} \mathrm{g}^{-1}$ (AJASA et al., 2004). In the present study, cadmium was the metal present in the lowest concentrations, being in the range from 0.9 to $1.0 \mu \mathrm{g} \mathrm{g}^{-1}$ in the korarima seeds and from 1.3 to $2.0 \mu \mathrm{g} \mathrm{g}^{-1}$ in the soil samples analysed. The permissible limit set by FAO (1984) for Cd in edible plants is $0.21 \mathrm{\mu g} \mathrm{g}^{-1}$, although toxic effects have been observed in man from the regular consumption of plants in excess of $3 \mu \mathrm{g} \mathrm{g}^{-1}$ (AJASA et al., 2004). The present study shows that $\mathrm{Cd}$ was accumulated slightly above this limit. This high level of cadmium might be due to the use of cadmium-containing phosphate fertilizers, or from the 
practice of growing these plants on soil amended with sewage sludge, or both.

The total lead content in agricultural soils lies between 2 and $200 \mu \mathrm{g} \mathrm{g}^{-1}$ (YEMENE et al., 2008), but in the present study, the lead concentrations in both the korarima seed and soil samples were below the method detection limit. However, values as high as 0.4, 0.6 and $0.78 \mu \mathrm{g} \mathrm{g}^{-1}$ have been reported in spices of the same family (KREJPCIO et al., 2007; AL-EED et al., 2002). The permissible limit set by FAO (1984) for $\mathrm{Pb}$ in edible plants is $0.43 \mu \mathrm{g} \mathrm{g}^{-1}$. Therefore further investigation using alternative methods for the determination of lead and a larger sample size may be necessary to obtain a firm conclusion.

According to (AL-EED et al., 2002), for a daily intake of about $20 \mathrm{~g}$ of spices, there is no risk to humans from the spice under study for hazardous $\mathrm{Pb}, \mathrm{Cd}$ and $\mathrm{Co}$ levels. The results from the present study also showed that most of the metals evaluated fell within the safe range.

In general, the differences in metal concentrations in plants from different sites are related to the conditions from where the samples were collected. This means that the variation between the different sites for the levels of some elements could be attributed to different factors such as geographical and climatic variation, differences in physicochemical nature of the soil and differences in the agricultural practices and inputs used for plant growth.

The results of the analyses showed that the spice analysed in the present study contained appropriate concentrations of essential and non-essential metals, and could therefore be a source of mineral nutrients for those who consume it regularly. Though much is known about the functional role of a number of metals, the best foreseeable benefit from mineral nutrition for human health lies in obtaining the correct amount of supplementation in the right form at the right time. It has been shown that the medicinal values of some plant species used in homeopathic systems may be due to the presence of $\mathrm{Ca}, \mathrm{Cr}, \mathrm{Cu}, \mathrm{Fe}, \mathrm{Mg}, \mathrm{K}$ and $\mathrm{Zn}$. Metals like $\mathrm{Cr}$, Mg and $\mathrm{Zn}$ have important roles in the metabolism of cholesterol as well as in heart diseases. The presence of $\mathrm{Cr}$ and $\mathrm{Mn}$ in plants may be correlated with therapeutic properties against diabetes and cardiovascular diseases and a deficiency or excess of $\mathrm{Cu}, \mathrm{Mn}, \mathrm{Zn}, \mathrm{Cr}, \mathrm{Ca}, \mathrm{Mg}$ and $\mathrm{K}$ may cause a number of disorders. These metals also take part in neurochemical transmission and serve as constituents of biological molecules, as a cofactor for various enzymes and in a variety of different metabolic processes (AJASA et al., 2004).

Considering the above, the spice under study is a source of biologically important elements, which may play a part in the above mentioned therapeutic properties. Hence it is expected that plants with high concentrations of the above-mentioned macro and micronutrients, which in most cases were present in permissible levels, might play an important role in the maintenance of human health. Thus one must analyse the plants for their elemental contents, which are highly relevant for the assessment of the plant's nutritional and toxic quality. The present study illustrated the accumulation of metals at various levels in the spice under investigation, harvested in the south and southwest of Ethiopia (AJASA et al., 2004).

\subsection{Comparison of the metal levels found in the present study with those found in the literature}

In the present study the levels of metals found in korarima seeds were compared with the values found in the literature for similar plant species and spices. The korarima plant is indigenous to Ethiopia and no studies have been carried on the metal contents of this spice. Therefore, the metal levels in small cardamom (Elettaria cardamomum), large cardamom (Amomum subulatum) and ginger (Zingiber officinale) were used for comparison in the present study (Tables 2 and 3). The data presented in Tables 2 and 3 clearly indicated that most of the values reported in the literature were in agreement with those found the present study, especially for the essential metals investigated. The level of iron in the spices used for comparison ranged from: 13.3-2475 $\mathrm{\mu g} \mathrm{g}^{-1}$, while the value determined in the present study was from: 37.0-46.3 $\mathrm{Mg} \mathrm{g}^{-1}$, which lies within the range. The mean concentration of $\mathrm{Zn}$ was from 3.4-50.6 in the literature and from 12.3-17.9 $\mathrm{ug} \mathrm{g}^{-1}$ in the present study. The level of copper reported in the literature was to the order of $1.7-48.2 \mu \mathrm{g} \mathrm{g}^{-1}$ whereas in the present study it was from $5.8-8.3 \mu \mathrm{g} \mathrm{g}^{-1}$. Thus the concentrations of both zinc and copper were within the ranges reported in the literature.

\subsection{Analysis of variance}

Variations between the samples in the mean levels of the metals were tested to determine whether it was just a random error or the treatment (i.e. difference in the mineral composition of the soil, climatic conditions, soil inputs such as fertilizers, pesticides or herbicides, or variations in soil parameters such as the $\mathrm{pH}$ ) using one-way ANOVA.

The result indicated that significant differences were obtained $(p<0.05)$ at the 95\% confidence level for $\mathrm{Ca}, \mathrm{Mg}, \mathrm{Zn}, \mathrm{Cu}, \mathrm{Mn}$ and $\mathrm{Cr}$ in the korarima seed samples collected from the Bonga, Gamo Gofa and Metu sites, although the variations for $\mathrm{Fe}, \mathrm{Ni}, \mathrm{Co}$ and $\mathrm{Cd}$ were not significant $(p>0.05)$. For the soil samples analysed, with the exception of $\mathrm{Zn}, \mathrm{Cr}$ and $\mathrm{Co}$, all the metals (Ca, Mg, $\mathrm{Fe}, \mathrm{Cu}, \mathrm{Mn}, \mathrm{Ni}$ and $\mathrm{Cd}$ ) differed significantly.

\subsection{Pearson correlation of the metals}

The correlation between the metals in the korarima seed and soil samples was investigated using Pearson 
Table 2. Summary of the comparison of the levels of the metals ( $\mathrm{Ca}, \mathrm{Mg}$, Fe, $\mathrm{Zn}$ and $\mathrm{Cu}$ ) reported for small cardamom, large cardamom and ginger with those found in the present study.

\begin{tabular}{|c|c|c|c|c|c|c|}
\hline \multirow{2}{*}{ Spices } & \multicolumn{5}{|c|}{ Metals ( $\mu \mathrm{g} \mathbf{g}^{-1}$ dry wt) } & \multirow{2}{*}{ References } \\
\hline & $\mathbf{C a}$ & Mg & $\mathrm{Fe}$ & $\mathbf{Z n}$ & $\mathrm{Cu}$ & \\
\hline \multirow{2}{*}{$\begin{array}{c}\text { Small } \\
\text { cardamom }\end{array}$} & - & - & $441 \pm 61$ & $50.6 \pm 2.6$ & $48.2 \pm 20.6$ & Ansari et al. (2004) \\
\hline & - & - & $73 \pm 2.2$ & $25 \pm 0.8$ & $5 \pm 0.7$ & Ozkutlu et al. (2006) \\
\hline $\begin{array}{c}\text { Large } \\
\text { cardamom }\end{array}$ & - & - & $285 \pm 44$ & $45.3 \pm 5.2$ & $14 \pm 3.3$ & Ansari et al. (2004) \\
\hline \multirow{6}{*}{ Ginger } & - & - & $2475 \pm 1110$ & $19.7 \pm 1.9$ & $49.4 \pm 2.7$ & Ansari et al. (2004) \\
\hline & - & - & - & $5.0 \pm 0.9$ & $3.0 \pm 0.8$ & Ozkutlu et al. (2006) \\
\hline & - & - & - & $4.8 \pm 0.05$ & - & $\begin{array}{l}\text { Aiwonegbe and Ikhuoria } \\
\text { (2007) }\end{array}$ \\
\hline & - & - & $13.3 \pm 0.01$ & $3.4 \pm 0.02$ & $1.7 \pm 0.01$ & Hashmi et al. (2007) \\
\hline & - & - & - & - & $2.35-8.3$ & Krejpcio et al. (2007) \\
\hline & $2610 \pm 10$ & $4210 \pm 10$ & $144 \pm 0.05$ & $33.3 \pm 0.01$ & $14.4 \pm 0.01$ & Ajasa et al. (2004) \\
\hline Korarima & $1794 \pm 2181$ & $1626 \pm 2067$ & $37.0 \pm 46.3$ & $12.3 \pm 17.9$ & $5.8 \pm 8.3$ & Present study \\
\hline Cardamom & $2719 \pm 35$ & $2390 \pm 41$ & $64.8 \pm 2.2$ & $19.6 \pm 0.9$ & $9.5 \pm 1.0$ & Present study \\
\hline
\end{tabular}

Table 3. Summary of the comparison of the levels of the metals (Co, $\mathrm{Cr}, \mathrm{Mn}, \mathrm{Ni}, \mathrm{Pb}$ and $\mathrm{Cd}$ ) reported for small cardamom, large cardamom and ginger with those found in the present study.

\begin{tabular}{|c|c|c|c|c|c|c|c|}
\hline \multirow{2}{*}{ Spices } & \multicolumn{6}{|c|}{ Metals ( $\mu \mathrm{g} \mathrm{g} \mathrm{g}^{-1}$ dry wt) } & \multirow{2}{*}{ References } \\
\hline & Co & $\mathrm{Cr}$ & Mn & $\mathrm{Ni}$ & $\mathbf{P b}$ & Cd & \\
\hline \multirow{3}{*}{$\begin{array}{c}\text { Small } \\
\text { cardamom }\end{array}$} & - & - & $2840 \pm 112$ & - & - & - & Ansari et al. (2004) \\
\hline & - & - & $168 \pm 2.5$ & - & - & $0.15 \pm 5.2$ & Ozkutlu et al. (2006) \\
\hline & ND & - & & - & 0.4 & 0.14 & Al-Eed et al. (2002) \\
\hline $\begin{array}{l}\text { Large } \\
\text { cardamom }\end{array}$ & - & - & $223 \pm 18$ & - & - & - & Ansari et al. (2004) \\
\hline \multirow{6}{*}{ Ginger } & - & - & $1014 \pm 52$ & - & - & - & Ansari et al. (2004) \\
\hline & - & - & $73 \pm 3.4$ & - & - & $0.072 \pm 4.1$ & Ozkutlu et al. (2006) \\
\hline & 0.32 & - & - & - & 0.6 & 0.07 & Al-Eed et al. (2002) \\
\hline & - & $0.04 \pm 0.01$ & - & $0.21 \pm 0.03$ & 0.01 & $0.012 \pm 0.03$ & $\begin{array}{l}\text { Aiwonegbe and Ikhuoria } \\
\qquad(2007)\end{array}$ \\
\hline & - & - & - & - & $0.21-0.78$ & $0.02-0.04$ & Krejpcio et al. (2007) \\
\hline & - & $0.05 \pm 0.01$ & $1.6 \pm 0.01$ & - & - & - & Hashmi et al. (2007) \\
\hline Korarima & $2.0-2.3$ & $3.8-5.8$ & $143.8-179.6$ & $6.6-8.5$ & ND & $0.9-1.0$ & Present study \\
\hline Cardamom & $2.6 \pm 0.2$ & $8.3 \pm 0.7$ & $355.4 \pm 9.8$ & $11.7 \pm 0.5$ & ND & $0.87 \pm 0.07$ & Present study \\
\hline
\end{tabular}

correlation matrices, thus obtaining the correlation coefficients. For the majority of the metals analysed, with the exception of cadmium, magnesium and copper in the korarima seeds, and cadmium, cobalt, zinc and chromium in the soil samples, the correlation was significant $(r>0.8)$ at the 95\% confidence level. Moreover, cadmium showed a negative correlation with almost all the metals analysed in both samples, which showed a weak association with the other metals. A very high (nearly 1) positive correlation indicates a strong association between the metals, which may arise from natural sources or the environment or from a similarity in the chemical properties. Magnesium with copper in the plants and manganese with cobalt in the soil showed negative correlations.
The correlation coefficients $(r)$ between the metals in the korarima seeds and soil samples collected from each of the three sites were calculated separately for each metal (Table 4). The results indicated there was good correlation between some of the metals ( $\mathrm{Ni}, \mathrm{Fe}, \mathrm{Cd}, \mathrm{Ca}$, $\mathrm{Cu}, \mathrm{Mg}$ ) in the korarima seeds and soil samples, but poor correlation between some of the metals ( $\mathrm{Cr}, \mathrm{Zn}, \mathrm{Mn}, \mathrm{Co})$ in the two types of samples in the region investigated. Good correlations were expected between the metal contents in the soil and the plants, since the plants take up nutritional metals from the soil via their roots. The poor correlation observed for some of the metals could have been due to the fact that some metals may be assimilated to a lesser extent by the plant although present in high concentrations 
Levels of selected essential and non-essential metals in seeds of korarima (Aframomum corrorima) cultivated in Ethiopia MEKASSA, B.; CHANDRAVANSHI, B. S.

Table 4. Pearson's correlation between the metals in the korarima seed and soil samples.

\begin{tabular}{ccccccccccc} 
Metals & $\mathbf{C a}$ & $\mathbf{M g}$ & $\mathbf{M n}$ & $\mathbf{F e}$ & $\mathbf{Z n}$ & $\mathbf{C u}$ & $\mathbf{N i}$ & $\mathbf{C r}$ & $\mathbf{C o}$ & $\mathbf{C d}$ \\
$\mathrm{R}$ & 0.879 & 0.779 & 0.483 & 0.989 & 0.551 & 0.824 & 0.999 & 0.583 & 0.327 & 0.981 \\
\hline
\end{tabular}

in the soil, since they may not be available in the soluble forms absorbed by the plant.

\section{Conclusions}

The study indicated the presence of essential metals ( $\mathrm{Ca}, \mathrm{Mg}, \mathrm{Fe}, \mathrm{Zn}, \mathrm{Cu}, \mathrm{Co}, \mathrm{Cr}, \mathrm{Mn}, \mathrm{Ni}$ ) and one non-essential metal $(\mathrm{Cd})$ in the korarima seed and soil samples. The level of $\mathrm{Cd}$ in the korarima seeds was 0.9-1.0 $\mathrm{Mg} \mathrm{g}^{-1}$, but the other non-essential metal (Pb) was not detected in any of the samples investigated.

The investigation of the metal levels also revealed that for most of the metals determined, there was a direct relationship between the levels in the korarima seeds and those in the soil in which the plant was grown. The study also showed that the metals were present at different concentrations in the samples from different sites. Comparable results were found with some of the values reported in the literature and for some of the metals the concentrations slightly exceeded the permissible levels, which could be attributed to the agricultural practices employed such as the use of fertilizers and herbicides.

In general the consumption of spices by humans in their daily food is negligible as compared to that of other food items, since they are added or used in very small amounts. Thus, considering this, the concentrations of the metals were relatively small, particularly those of the non-essential metals, which means that the levels of the metals were in accordance with the recommended dietary allowances (RDA) or within the permissible limits set by $\mathrm{FAO} / \mathrm{WHO}$ for edible plants, and hence there is no risk from using the spice under study in the food. However, since there is a growing interest in the use of spices throughout the world, special attention should be given to a continuous monitoring of the levels of trace metals, particularly the non-essential ones, since they accumulate with time and cause serious health impacts.

\section{Acknowledgements}

The authors are grateful to the Department of Chemistry, Addis Ababa University, Ethiopia, for providing the laboratory facilities.

\section{References}

AIWONEGBE, A. E.; IKHUORIA E. U. Levels of selected heavy metals in Nigerian vegetables. Trends in Applied Sciences Research, New York, v. 2, n. 1, p. 76-79, 2007. http://dx.doi. org/10.3923/tasr.2007.76.79.
AJASA, A. M. O.; BELLO, M. O.; IBRAHIM, A. O.; OGUNWANDE, I. A.; OLAWORE, N. O. Heavy trace metals and macronutrients status in herbal plants of Nigeria. Food Chemistry, London, v. 85 , n. 1, p. 67-71, 2004. http://dx.doi.org/10.1016/j. foodchem.2003.06.004.

AL-EED, M. A.; ASSUBAIE, F. N.; EL-GARAWANY, M. M.; EL-HAMSHARY, H.; ELTAYEB, Z. M. Determination of heavy metal levels in common spices. Journal of Applied Science, Pakistan, v. 17, p. 87-98, 2002.

ANSARI, T. M.; IKRAM, N.; NAJAM-UL-HAQ, M.; FAYYAZ, I.; FAYYAZ, Q.; GHAFOOR, I.; KHALID, N. Essential trace metal (zinc, manganese, copper and iron) levels in plants of medicinal importance. The Journal of Biological Sciences, New York, v. 4, n. 2, p. 95-99, 2004. http://dx.doi.org/10.3923/jbs.2004.95.99.

díAZ-MAROTO, M. C.; PÉREZ-COELLO, M. S.; CABEZUDO, M. D. Headspace solid-phase microextraction analysis of volatile components of spices. Chromatographia, New York, v. 55, n. 11-12, p. 723-728, 2002. http://dx.doi.org/10.1007/BF02491788.

DIVRIKLI, U.; HORZUM, N.; SOYLAK, M.; ELCI, L. Trace heavy metal contents of some spices and herbal plants from Western Anatolia, Turkey. International Journal of Food Science \& Technology, Oxford, v. 41, n. 6, p. 712-716, 2006. http://dx. doi. org/10.1111/j.1365-2621.2005.01140.x.

etONiHU, A. C.; OBELle, F. N.; NWEZE, C. C. Chemical perspectives on some readily consumed spices and food condiments. Food Science and Quality Management, New Delhi, v. 15, p. 10-20, 2013.

EYOB, S.; APPELGREN, M.; ROHLOFF, J.; TSEGAYE, A.; MESSELE, G. Chemical composition of essential oils from fresh plant parts of korarima (Aframomum Corrorima) cultivated in the highlands of Southern Ethiopia. Journal of Essential Oil Research, Carol Stream, v. 19, n. 4, p. 372-375, 2007. http:// dx.doi.org/10.1080/10412905.2007.9699308.

EYOB, S.; MARTINSEN, B. K.; TSEGAYE, A.; APPELGREN, M.; SKREDE, G. Antioxidant and antimicrobial activities of extract and essential oil of korarima (Aframomum Corrorima (Braun) PCM Jansen). African Journal of Biotechnology, Lagos, v. 7 , n. 15, p. 2585-2592, 2008

EYOB, S. Promotion of seed germination, subsequent seedling growth and in vitro propagation of korarima (Aframomum Corrorima (Braun) PCM Jansen). Journal of Medicinal Plant Research, Lagos, v. 3, n. 9, p. 652-659, 2009.

EYOB, S.; TSEGAYE, A.; APPELGREN, M. Analysis of korarima (Aframomum corrorima (Braun) P.C.M. Jansen) indigenous production practices and farm based biodiversity in southern Ethiopia. Genetic Resources and Crop Evolution, Dordrecht, 
Levels of selected essential and non-essential metals in seeds of korarima (Aframomum corrorima) cultivated in Ethiopia MEKASSA, B.; CHANDRAVANSHI, B. S.

v. 56, n. 4, p. 573-585, 2009. http://dx.doi.org/10.1007/s10722008-9387-x.

FOOD AND AGRICULTURE ORGANIZATION OF UNITED NATIONS - FAO; WORLD HEALTH ORGANIZATION - WHO. Format of codex commodity standards. In: FOOD AND AGRICULTURE ORGANIZATION OF UNITED NATIONS FAO; WORLD HEALTH ORGANIZATION - WHO (Ed.). Codex alimentarius commission: procedural manual. Rome: $\mathrm{FAO} /$ WHO, 1984. p. 43-49. (v. XVII).

HASHMI, D. R.; ISMAIL, S.; SHAIKH, G. H. Assessment of the level of trace metals in commonly edible vegetables locally available in the markets of Karachi City. Pakistan Journal of Botany, Karachi, v. 39, n. 3, p. 747-751, 2007

HYMETE, A.; ROHLOFF, J.; HIVERSEN, T. H. Essential oil from seeds and husks of korarima (Aframomum Corrorima) from Ethiopia. Flavour and Fragrance Journal, Chichester, v. 21, n. 4, p. 642-644, 2006. http://dx.doi.org/10.1002/ffj.1634.

JABEEN, S.; SHAH, M. T.; KHAN, S.; HAYAT, M. Q. Determination of major and trace elements in ten important folk therapeutic plants of Haripur Basin, Pakistan. Journal of Medicinal Plant Research, Lagos, v. 4, n. 7, p. 559-566, 2010.

KREJPCIO, Z.; KRÓL, E.; SIONKOWSKI, S. Evaluation of heavy metals contents in spices and herbs available on the polish market. Polish Journal of Environmental Studies, Olsztyn, v. 16, n. 1, p. 97-100, 2007.

LEISTRITZ, W. Methods of bacterial reduction in spices. In: RISCH, S. J.; HO, C. T. (Ed.). Spices flavor chemistry and antioxidant properties. Washington: American Chemical Society, 1997. chap. 2, p. 7-10. Developed from a symposium sponsored by the division of Agricultural and Food Chemistry.

NATIONAL RESEARCH COUNCIL - NRC. Minerals. In: NATIONAL RESEARCH COUNCIL - NRC. (Ed.). Recommended dietary allowances. 10th ed. Washington, The National Academy of Sciences Press, 1989a. chap. 9, p. 174-194. (Dietary Reference Intakes). Available at: <http://www.nap.edu/openbook. php?record_id=1349\&page $=174>$. Accessed on: 10 Sept. 2014.
NATIONAL RESEARCH COUNCIL - NRC. Trace elements. In: NATIONAL RESEARCH COUNCIL - NRC. (Ed.). Recommended dietary allowances. 10th ed. Washington: The National Academy of Sciences Press, 1989b. chap. 10, p. 195-246. (Dietary Reference Intakes). Available at: <http://www.nap.edu/ openbook. php?record_id=1349\&page $=195>$. Accessed on: 10 Sept. 2014.

OZKUTLU, F.; SEKEROGLU, N.; KARA, S. M. Monitoring of cadmium and micronutrients in spices commonly consumed in Turkey. Research Journal of Agriculture and Biological Sciences, Pakistan, v. 2, p. 223-226, 2006.

RANDJELOVIC, S. S.; KOSTIC, D. A.; STOJANOVIC, G. S.; MITIC, S. S.; MITIC, M. N.; ARSIC, B. B.; PAVLOVIC, A. N. Metals content of soil, leaves and wild fruit from Serbia. Central European Journal of Chemistry, Warsaw, v. 12, n. 11, p. 11441151, 2014. http://dx.doi.org/10.2478/s11532-014-0566-7.

RISCH, S. J. Spices: sources, processing, and chemistry. In: RISCH, S. J.; HO, C. T. (Ed.). Spices flavor chemistry and antioxidant properties. Washington: American Chemical Society. chap. 1, p. 2-6, 1997. Developed from a symposium sponsored by the division of Agricultural and Food Chemistry.

TEFERA, W.; WANNAKRAIROJ, S. Synergistic effects of some plant growth regulators on in vitro shoot proliferation of korarima (Aframomum Corrorima (Braun) Jansen). African Journal of Biotechnology, Lagos, v. 5, n. 10, p. 1894-1901, 2006.

UMAR, M. A.; SALIHU, Z. O. O. Heavy metals content of some spices available within FCT-Abuja, Nigeria. International Journal of Agricultural and Food Science, Ottawa. v. 4, n. 1, p. 66-74, 2014.

YEMENE, M.; CHANDRAVANSHI, B. S.; WONDIMU, T. Levels of essential and non-essential metals in leaves of the tea plant (Camellia Sinensis L.) and soils of wushwush farms, Ethiopia. Food Chemistry, London, v. 107, p. 1236-1243, 2008. 